\title{
Feeding Habits of the Bogue, Boops boops (Linnaeus, 1758) (Teleostei: Sparidae) in Benghazi Coast, Eastern
}

\section{Libya}

\author{
Hamad El-Maremie ${ }^{1}$ and Mohammad El-Mor ${ }^{2,3}$ \\ 1. Marine Resources Department, Faculty of Natural, Resources and Environmental Science, Omar Al-Mokhtar University, \\ Al-Bayda 919, Libya \\ 2. Zoology Department, Faculty of Science, Omar Al-Mokhtar University, Al-Bayda 919, Libya \\ 3. Marine Science Department, Faculty of Science, Suez Canal University, Ismailia 41611, Egypt
}

Received: February 7, 2014 / Accepted: May 6, 2015 / Published: May 30, 2015.

\begin{abstract}
The feeding habits of 500 specimens of Boops boops (family: Sparidae), inhabiting Benghazi Mediterranean coast, were studied monthly from November 2012 to October 2013. The annual diet composition, monthly variations in the diet composition, the variations of diet with length and the intensity of feeding were studied. Boops boops feed on a wide variety of prey types: Crustacean (49.0\%), Porifera (22.7\%), Coelenterate (10.2\%), Seagrasses (9.2\%), Mollusca (8.1\%) and Protozoa (0.9\%). The Crustacean, Porifera, Coelenterate, Seagrasses and Mollusca were the major food item all year round and it was found in all length groups. In the present study, Crustacean, Porifera, Seagrasses and Mollusca increased as the size increased while Coelenterate and Protozoa decreased as the fish size increased. The feeding intensity was quite high during the autumn and summer.
\end{abstract}

Key words: Feeding habits, Boops boops, eastern coast, Mediterranean Sea, Libya.

\section{Introduction}

Sparid fishes inhabit tropical and temperate coastal water. Fish individuals are swimming near the shore in shallow inlet and bays at moderate depth. Family Sparidae comprise about 22 genera in four subfamilies containing 41 species [1]. Fourteen species were recorded in the Libyan coast, such as Diplodus annularis, Pagrus pagrus, Dentex dentex, Diplodus vulgaris, Lithognathus mormyrus, Oblada melanura, Sarpa salpa and Boops boops [2]. The Bogue is one of the fishes in family Sparidae, is one of the most popular sparid fish species in the Mediterranean region and the Atlantic coast [3], the fish had been characterized by high price value, a highly appreciated flesh and good market perspectives. Although the

Corresponding author: Hamad El-Maremie, assistant professor, research fields: fish biology and aquaculture. E-mail: elmaremie@yahoo.com.
Bogue, subtropical; $63^{\circ} \mathrm{N}-16^{\circ} \mathrm{S}, 26^{\circ} \mathrm{W}-42^{\circ} \mathrm{E}$ found in a wide variety of locations in Atlantic and Mediterranean Sea, its status is considered endangered [4]. From the available literature, it was found that few works have been published on the biology of Sparid fishes in the study area [5-7]. Laith [5] studied asymmetry in some morphological characters of four Sparid fishes in Benghazi coast. Froglia [8] stated that feeding biology of Sparid fish Lithognathus mormyrus in Central Adriatic, he concluded that the species feed on a wide variety of prey types: Crustacean, polychaetes, molluscs and echinoderms, also Ahmed [9] studied the feeding biology for the same previous species in the same previous area and he stated that the species feed on Crustacean, polychaetes, molluscs, echinoderms, fish parts and Seagrasses. Ali [10] stated that feeding biology of Sparid fish Pagrus pagrus in Souse coast, eastern Libya, she concluded that the 
species feed on a wide variety of prey types: Crustacean, polychaetes, molluscs, echinoderms, fish parts, Seagrasses and foraminifera. El-Mor and ElMaremie [11] studied feeding habits of the nockt Diplodus noct in southern Sinai, Gulf of Suez, Red Sea Egypt, they stated that the species feed on a wide variety of prey types, fish parts, Crustacean, sea grasses, molluscs, algae and copepods.

This is the first study so far on the feeding habits of Bogue (family Sparidae) in Libyan eastern coast. Boops boops position in the trophic structure of the Libyan eastern coast is poorly understood. So the aim of the present study is defining the trophic relationships between Bogue with other invertebrates and fishes in this area, in order to understand the dynamic of this regional ecosystem. Beside results from feeding habits of Bogue may have direct implications for aquaculture.

\section{Materials and Methods}

Monthly samples of $D$ Boops boops were collected during the period from November 2012 to October 2013 by using gill and trammel nets from artisanal fishing in Benghazi fishing harbour $32^{\circ} 36^{\prime} \mathrm{N}$ and $20^{\circ} 03^{\prime} \mathrm{E}$ on the Mediterranean (Fig. 1). A total of 500 specimens of Boops boops were sampled for studying the feeding habits. Feeding Habits of the Bogue, Boops boops (Linnaeus, 1758) from Benghazi Coasts, Libya Annual, diet composition, seasonal variations of diet, variations of diet with lengths and feeding intensity were estimated in this study. For each fish specimen total length measured to the nearest $0.1 \mathrm{~cm}$. Each fish was dissected and the alimentary tract was removed and preserved in formalin. The degree of fullness of the stomach was assessed by visual estimation and classified as empty, trace, quarter full, half full, three quarters full and completely full respectively as described in Ref. [12].

Food items were identified to their groups. A list of general diet composition was made food analysis was made by points of assessment [13, 14]. The results were statistically analysis subjected to the further statistical treatment according to Godfriaux [15] in order to give more precise information about food and feeding habits of Boops boops.

\section{Results}

\subsection{Annual Diet Composition}

The variety of food items was large (Fig. 2). However, Crustacean supplemented by Porifera formed the major food groups for Boops boops. Crustacean made up of $49.0 \%$ by volume composition of the bulk of the diet which represented by small prawns and copepods, whereas Porifera (22.7\%) coming in the second position of importance, which represented by sponges. Coelenterate $(10.2 \%)$ was composed of jellyfish. The other food items were Seagrasses constituting 9.2\%, which was mainly represented by Cymodocea nodosa, Halophila stipulacea and Posidonia Ocaenica, this followed by Mollusca (8.1\%) including bivalve animals, this followed by Protoza $(0.9 \%)$, such as Foraminifers.

\subsection{Monthly Variations in Diet Composition}

Food items were occurred in all year round during the study. The Crustacean, Porifera, Coelenterate, Seagrasses and Mollusca, constituted the major food items all year round during the study (Table 1). Table 2 showed seasonally variations in diet composition for 500 specimens Boops boops in Benghazi coast during the study period, in autumn the fish preferred Crustacean $(41.8 \%)$ and Porifera $(25.5 \%)$. In winter the fish ingested on Crustacean (49.7\%) and Porifera (23.1\%). While Crustacean represented by $(51.8 \%$ and $52.7 \%$ ) and Porifera (23.1\% and $19.3 \%)$ in spring and summer respectively. Foraminifers (Protoza) were completely absent in winter, spring and summer.

\subsection{Feeding Habit in Relation to Fish Size}

The total length of Boops boops population classified into 11 classes ranged from $9.5 \mathrm{~cm}$ to 31.4 $\mathrm{cm}$ with $1.9 \mathrm{~cm}$ interval (Table 3). Prey size differed 


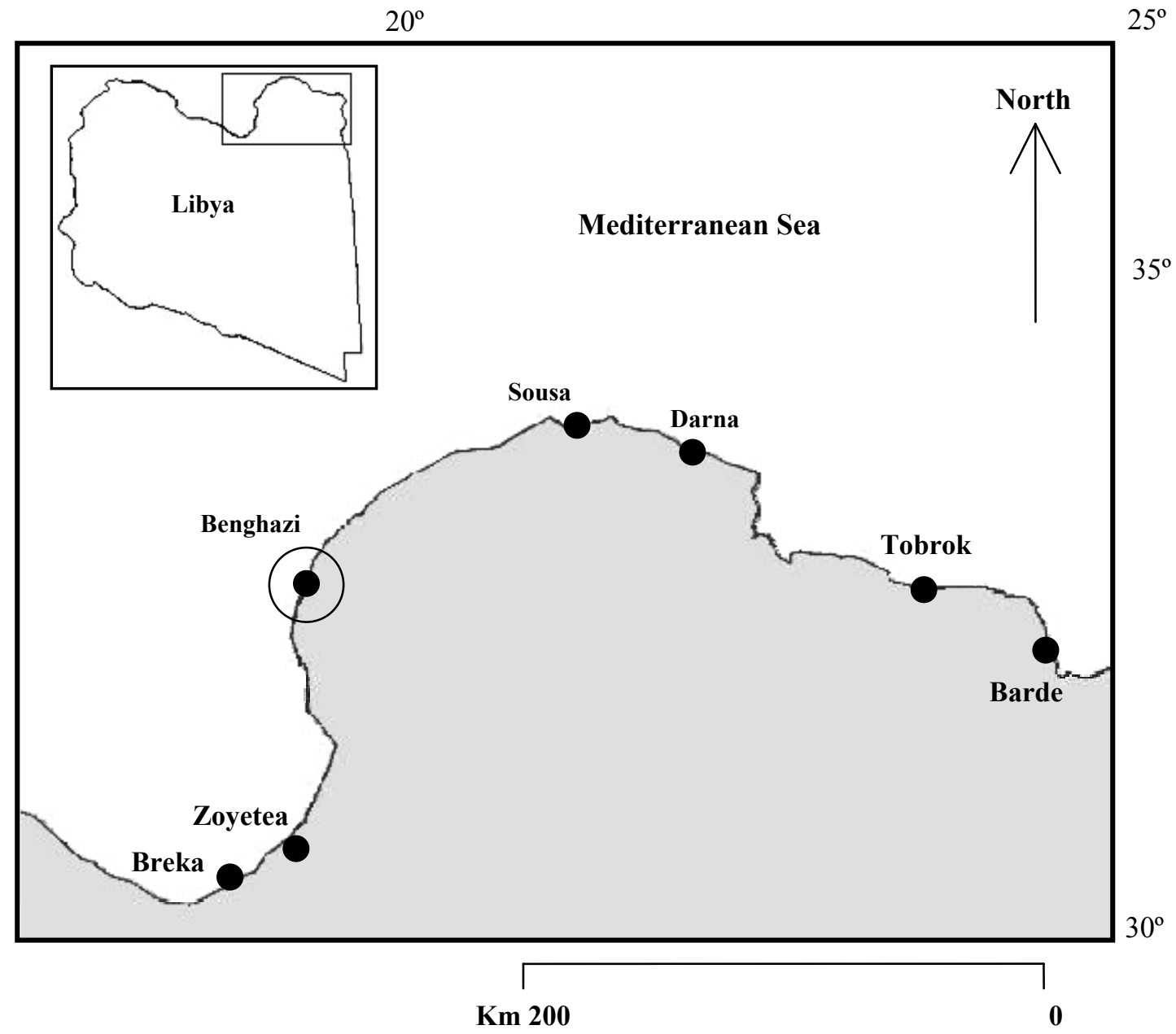

Fig. 1 Benghazi fishing harbor, on the Mediterranean, Libya.

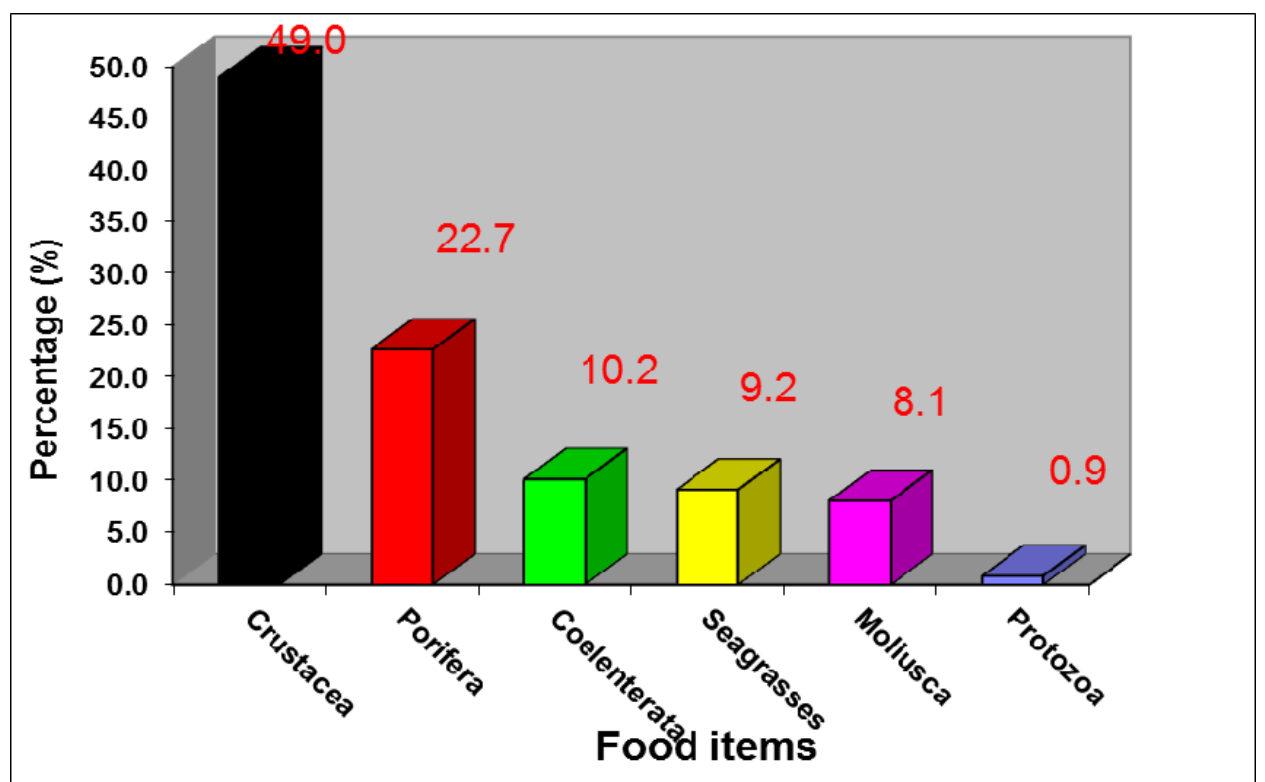

Fig. 2 The diet composition of Boops boops from Benghazi Coast, eastern Libya during the period from November 2012 till October 2013. 
Table 1 Monthly variations in diet composition of Boops boops from Benghazi Coast, eastern Libya during the period from November 2012 till October 2013.

\begin{tabular}{|c|c|c|c|c|c|c|c|}
\hline \multirow[b]{2}{*}{ Months } & \multirow[b]{2}{*}{ No. } & \multirow[b]{2}{*}{ Crustacea } & \multicolumn{3}{|c|}{ Food items } & \multirow[b]{2}{*}{ Mollus ca } & \multirow[b]{2}{*}{ Protozoa } \\
\hline & & & Porifera & Coelenterata & Seagrasses & & \\
\hline Nov.(2012) & 43 & 39.1 & 26.1 & 4.4 & 22.1 & 8.3 & A \\
\hline Dec. & 44 & 46.1 & 27.5 & 9.2 & 17.1 & 0.1 & A \\
\hline Jan. (2013) & 39 & 47.9 & 29.4 & 10.1 & 6.1 & 6.6 & A \\
\hline Feb. & 42 & 55.0 & 12.3 & 12.1 & 11.8 & 8.8 & A \\
\hline Mar. & 43 & 48.1 & 20.1 & 11.1 & 16.3 & 4.3 & A \\
\hline Apr. & 49 & 55.5 & 26.6 & 13.8 & 0.7 & 3.5 & A \\
\hline May & 40 & 51.9 & 22.5 & 14.1 & 7.3 & 4.3 & A \\
\hline Jun. & 41 & 54.3 & 19.1 & 10.5 & 2.8 & 13.3 & A \\
\hline Jul. & 41 & 50.6 & 20.1 & 9.9 & 8.4 & 11.1 & A \\
\hline Aug. & 42 & 53.1 & 18.6 & 5.8 & 10.5 & 12.1 & A \\
\hline Sep. & 38 & 42.8 & 17.6 & 15.2 & 2.4 & 13.5 & 8.5 \\
\hline Oct. & 38 & 43.4 & 32.7 & 6.1 & 4.6 & 11.5 & 1.7 \\
\hline Total & 500 & 588 & 273 & 122 & 110 & 97 & 10 \\
\hline$\%$ & & 49.0 & 22.7 & 10.2 & 9.2 & 8.1 & 0.9 \\
\hline
\end{tabular}

Remarks: data expressed as percentage, $(\mathrm{A})=$ no food in month occurred.

Table 2 Seasonally variations in diet composition of Boops boops from Benghazi Coast, eastern Libya during the period from November 2012 till October 2013.

\begin{tabular}{|c|c|c|c|c|c|c|c|}
\hline Seasons & No. of fish & Crustacea & Porifera & Coelenterata & Seagrasses & Mollusca & Protozoa \\
\hline & & & & & & & \\
Autumn & 119 & 41.8 & 25.5 & 8.6 & 9.7 & 11.1 & 3.4 \\
\hline Winter & 125 & 49.7 & 23.1 & 10.5 & 11.7 & 5.2 & B \\
\hline & 132 & 51.8 & 23.1 & 13.0 & & & \\
Spring & & & & & & & \\
\hline \\
Summer
\end{tabular}

Remarks: data expressed as percentage, $(B)=$ no food in season occurred.

between large size individuals, which had ingested the large size prey, whereas the small sized fish ingested the small size prey. Crustacean, Porifera, Coelenterate, Seagrasses and Mollusca were found in all length groups of Boops boops.

In the present study, Crustacean, Porifera, Seagrasses and Mollusca increased as the size increased while Coelenterate and Protozoa decreased as the fish size increased. Crustacean were found in all length groups Boops boops, they increased from
$11.4 \%$ in size class $(9.5-11.4 \mathrm{~cm})$ to $42.5 \%$ in size class $(29.5-31.4 \mathrm{~cm})$. Porifera increased from $15.1 \%$ in size class $(9.5-11.4 \mathrm{~cm})$ to $25.5 \%$ in size class (29.5-31.4 cm), Coelenterate decreased from $46.7 \%$ in size class $(9.5-11.4 \mathrm{~cm})$ to $0.7 \%$ in size class $(29.5-31.4 \mathrm{~cm})$, Seagrasses ingested in size class $(9.5-11.4 \mathrm{~cm})$ by $1.6 \%$ increased in the following length groups and recorded the highest value $17.7 \%$ in size class $(29.5-31.4 \mathrm{~cm})$, Mollusca increased from $2.1 \%$ in size class $(9.5-11.4 \mathrm{~cm})$ to $13.5 \%$ in size class 
Table 3 The diet composition of different size classes Boops boops from Benghazi Coast, eastern Libya during the period from November 2012 till October 2013.

\begin{tabular}{|c|c|c|c|c|c|c|c|}
\hline \multirow{2}{*}{$\begin{array}{c}\text { Size groups } \\
\text { (cm) }\end{array}$} & \multirow[b]{2}{*}{ No. } & \multirow[b]{2}{*}{ Crustacea } & \multicolumn{3}{|c|}{ Food items } & \multirow[b]{2}{*}{ Mollusca } & \multirow[b]{2}{*}{ Protozoa } \\
\hline & & & Porifera & Coelenterata & Seagrasses & & \\
\hline $9.5-11.4$ & 41 & 11.4 & 15.1 & 46.7 & 1.6 & 2.1 & 23.1 \\
\hline $11.5-13.4$ & 42 & 18.6 & 18.8 & 43.6 & 5.5 & 4.5 & 9.1 \\
\hline $13.5-15.4$ & 47 & 29.3 & 21.2 & 33.1 & 7.7 & 8.8 & C \\
\hline $15.5-17.4$ & 44 & 34.1 & 24.1 & 23.2 & 9.1 & 9.5 & C \\
\hline $17.5-19.4$ & 41 & 34.5 & 24.4 & 22.1 & 9.4 & 9.7 & C \\
\hline $19.5-21.4$ & 42 & 34.8 & 24.5 & 18.3 & 10.8 & 11.6 & C \\
\hline $21.5-23.4$ & 45 & 35.1 & 24.9 & 10.5 & 16.8 & 12.7 & C \\
\hline $23.5-25.4$ & 48 & 41.7 & 25.1 & 2.8 & 17.3 & 13.1 & C \\
\hline $25.5-27.4$ & 49 & 41.9 & 25.3 & 1.3 & 17.4 & 13.2 & C \\
\hline $27.5-29.4$ & 46 & 42.3 & 25.4 & 1.2 & 17.6 & 13.4 & C \\
\hline $29.5-31.4$ & 55 & 42.5 & 25.5 & 0.7 & 17.7 & 13.5 & C \\
\hline
\end{tabular}

Remarks: data expressed as percentage, $(\mathrm{C})=$ no food in class occurred.

(29.5-31.4 cm), Protozoa ingested in length from 9.5 $\mathrm{cm}$ to $13.4 \mathrm{~cm}$ by $23.1 \%$ and $9.1 \%$ respectively then completely absent in the following size classes.

\subsection{Feeding Intensity}

Fishes with stomach half full, almost full and full of food ranked b\% constituted $58.8 \%$ of all analyzed individual, whereas those with stomach that were empty or with traces of food and quarter full ranked $a \%$ represented $41.2 \%$ of the total specimens (Table 4 ).

The feeding activities were quite high during autumn (69.9\%) and summer (86.7\%).

There are minimal rate of feeding intensity recorded in winter (29.5\%) and spring (49.1\%) (Table 5).

\section{Discussion}

The food and feeding habits of Sparid fishes have been studied by many authors [16-26].

The Bogue, Boops boops (family Sparidae) found on the shelf or coastal pelagic on various bottoms (sand, mud, rocks and seaweeds). Gregarious, ascending to the surface mainly at night. Omnivorous, feeding mainly on Crustaceans, also planktophagous.
Hermaphroditic, generally protogynous. Also caught in pelagic trawls [27].

In the current study, Boops boops were found to consume a wide range of food items such as Crustacean, Porifera, Coelenterate, Seagrasses, Mollusca and Protozoa. For the target species this is in full agreement with Abdel-Rahman and Bell [28, 29].

The Crustacean, Porifera, Coelenterate, Seagrasses and Mollusca, were the major food item all year round and it was found in all length groups. This is in full agreement with Ref. [30].

Generally, the food extent demands and ability for food acquisition increase with fish development [31].

Anato and Ktari [28] studied the feeding habits of the Bogue, Boops boops in Tunis Gulf waters on the Mediterranean Sea and they concluded that the numbers and size prey taxa increased with size of the annular sea bream due to the ability of larger fishes to consume a wide range of prey sizes than smaller fishes, this phenomenon appeared to be done for the target species in present work, In the present study Crustacean, Porifera, Seagrasses and Mollusca increased as the size increased while Coelenterate and 
Table 4 Monthly variations in the intensity of feeding of Boops boops from Benghazi Coast, eastern Libya during the period from November 2012 till October 2013.

\begin{tabular}{|c|c|c|c|c|c|c|c|c|c|}
\hline \multirow{2}{*}{ Months } & No.of fish & Empty & Trace & $1 / 4$ & a \% & $1 / 2$ & $3 / 4$ & Full & b \% \\
\cline { 2 - 10 } Nov.(2012) & 43 & $\mathrm{~A}$ & $\mathrm{~A}$ & 9.2 & 9.2 & 22.1 & 25.7 & 43.1 & 90.9 \\
\hline Dec. & 44 & 23.2 & 7.5 & 0.5 & 31.2 & 23.1 & 23.3 & 22.5 & 68.9 \\
\hline Jan. (2013) & 39 & 33.4 & 12.4 & 45.7 & 91.5 & 8.6 & $\mathrm{~A}$ & $\mathrm{~A}$ & 8.6 \\
\hline Feb. & 42 & 23.7 & 22.1 & 43.1 & 88.9 & 11.1 & $\mathrm{~A}$ & $\mathrm{~A}$ & 11.1 \\
\hline Mar. & 43 & 22.5 & 20.4 & 33.1 & 76 & 23.9 & $\mathrm{~A}$ & $\mathrm{~A}$ & 23.9 \\
\hline Apr. & 49 & 20.5 & 14.6 & 22.6 & 57.7 & 20 & 22 & 0.4 & 42.4 \\
\hline May & 40 & 18.8 & $\mathrm{~A}$ & $\mathrm{~A}$ & 18.8 & 24 & 24 & 33.1 & 81.1 \\
\hline Jun. & 41 & 13.5 & $\mathrm{~A}$ & $\mathrm{~A}$ & 13.5 & 25.2 & 27.6 & 33.8 & 86.6 \\
\hline Jul. & 41 & $\mathrm{~A}$ & $\mathrm{~A}$ & 8.7 & 8.7 & 26.7 & 28.9 & 35.6 & 91.2 \\
\hline Aug. & 42 & $\mathrm{~A}$ & $\mathrm{~A}$ & 17.7 & 17.7 & 27.7 & 14.4 & 40.1 & 82.2 \\
\hline Sep. & 38 & 6 & 8.5 & 17.4 & 31.9 & 22.1 & 15.4 & 30.6 & 68.1 \\
\hline Oct. & 38 & 16.6 & 20.5 & 12.3 & 49.4 & 16 & 12.2 & 22.5 & 50.7 \\
\hline Average & & & & & 41.2 & & & & 58.8 \\
\hline
\end{tabular}

Remarks: data expressed as percentage, $(\mathrm{A})=$ no food in month occurred.

Table 5 Seasonally variations in the intensity of feeding of Boops boops from Benghazi Coast, eastern Libya during the period from November 2012 till October 2013.

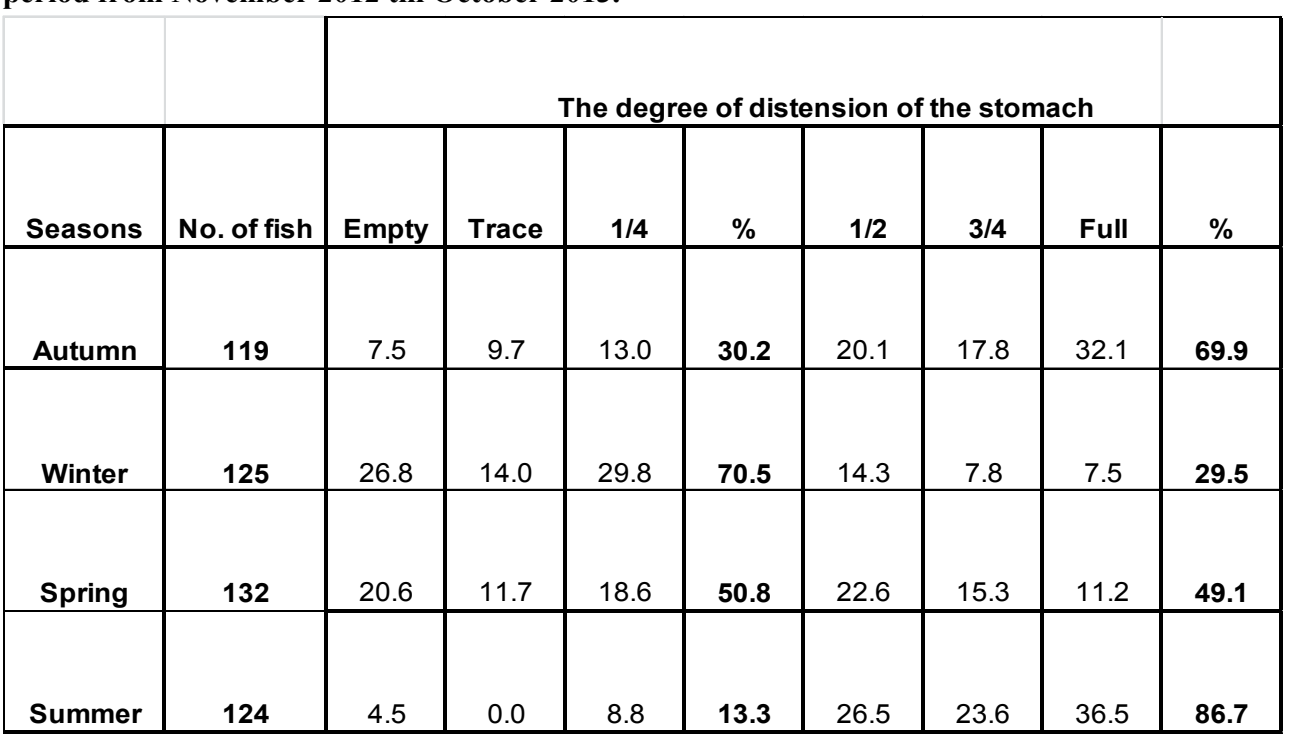

Remarks: data expressed as percentage.

Protozoa decreased as the fish size increased, which is in agreement with Sanchez-Velasco and Norbis [27].

The monthly variation in the condition factors fish is affected by the feeding activity which may show there reflection on the body condition [28], this phenomenon appears to be correct for species in the present work. The highest condition factor values $\left(\mathrm{K}_{\mathrm{f}}\right.$ and $\mathrm{K}_{\mathrm{c}}$ ) were recorded in autumn and summer, these results coincide with the degree of stomach fullness in ending spring, summer and autumn due to food 

in Benghazi Coast, Eastern Libya

availability [28]. This supports observations describe in the French Mediterranean Sea [29], and northwestern Mediterranean Sea [30].

\section{Conclusions}

In Ain EL-Ghazala Lagoon, eastern Libya Bogue, Boops boops (L. 1758) feed on a wide variety of prey types such as: Crustacean (49.0\%), Porifera (22.7\%), Coelenterate (10.2\%), Seagrasses (9.2\%), Mollusca $(8.1 \%)$ and Protozoa $(0.9 \%)$. The feeding intensity was quit high during the autumn and summer.

In the present study is defining the trophic relationships between Boops boops with other invertebrates and fishes in order to understand the dynamic of fish regional ecosystem.

From the feeding habits of the target species may have direct implication for aquaculture.

\section{References}

[1] Bauchot, M. L., and Smith, L. B. 1983. "For Sparidae." In Western Indian Ocean Fishing Area 51 Vol. 4, edited by Fisher, W. and Bianchi, G. Rome: FAO.

[2] Al-Hassan, L. A., and El-Silini, O. A. 1999. "Chick List of Bony Fishes Collected, from the Mediterranean Coast of Benghazi, Libya." Revista de Biologia, Marina Oceanografia 34: 291-301.

[3] Bauchot, M. L., and Hureau, J. C. 1990. "Sparidae." In Checklist of the Fishes of the Eastern Tropical Atlantic (CLOFETA), edited by Quero, G. C., Hureau, C., Karrer, C., Post, A. and Saldanha, L. Paris: UNESCO.

[4] Flgueiredo, J. L. de., and Dos Santos, A. P. 2002. Yamaguti economica exclusive da regiao sudeste-sul do Brasil, in Levantamento com Rede de Meia-Aqua-Saio-Paulo Editora da Universidade de sao Paulo, Imprensa official do Estado in Portuguese, pp. 242.

[5] Laith, A. J. 2003. "A Symmetry in Some Morphological Characters of Four Sparid Fishes from Benghazi Libya." Oceanological and Hydrobiological Studies 32 (3): 83-8.

[6] Ben-Abdallah, A. R., Alturky, A., and Fituri, A. 2005. "Records of Exotic Fishes in the Libyan." J. Mar. Sci. 10: $1-18$.

[7] Ekwella, S. A. 2008. "Environmental and biological Studies on Juvenile Commercial Fishes in El-Hamamh Coasts, El-Gabal-El-Akadar, Libya.” M.Sc. Thesis, Univ. of Omar Al Mukhtar.
[8] Froglia, C. 1977. "Feeding of Lithognathus mormyrus (L.) in Central Adriatic Sea (Pisces, Sparidae)." Rapp. Comm. Int. Mer Médit. 24: 95-7.

[9] Ahmed, A. I. 1999. "Biological and Ecological Studies on Some Sparidae Fishes from Southern Sinai Coasts (Red Sea)." Ph.D. Thesis, Faculty of Sci. Suez canal Univ.

[10] Ali, R. R. 2008. "Biological Studies on Pagrus pagrus from Sousa Coast (El-Gabal El-Akadar), Libyia.” M.Sc. Thesis, Univ. of Omar Al Mukhtar.

[11] El-Mor, M., and E-Maremie, H. A. 2008. "Feeding Habits of the Nokt Diplodus noct, from Southern Sinai, Gulf of Suez, Red Sea, Egypt." ARABIAN AQUACULTURE SOCIETY JOURNAL (3): 1-15.

[12] Pillay, T. V. R. 1952. "A Critique of the Methods of Study of Food of Fishes.” J. Zool-Soc. India 4: 181-199.

[13] Hyslop, E. J. 1980. "Stomach Content Analysis: Review of Methods and Their Application." J. Fish. Biol. 17: 411-29.

[14] Hynes, H. B. 1985. "The Food of Fresh Water (Ticklebacks Jardas, I., 1985: The Feeding of Juvenile Striped Sea Bream, Lithognathus mormyrus (L.) in the Central Adriatic Sea (Pisces, Sparidae)." Rapp. Comm. Int. Mer Médit. 29: 107-8.

[15] Godfriaux, B. L. 1969. "Food Predatory Demersal Fish in Hauraki Gulf. I. Food and Feeding Habits of the snaper Chrysophyrs auratus." N. Z. Mar. Fresh Res. 3: 518-44.

[16] Blaber, S. J. M. 1974. "Field Studies of Diet of Rhabdosargus holubi." J. Zool. Lond. 173: 407-17.

[17] Coetzee, P. S., and Baird, D. 1981. "Age, Growth and Food of Cheimerius nufar (Eherenberg, 1820) (Sparidae) Collected off st. Croix Island, Algoa Bay." S. Afr. G. Zool. 16: 137-43.

[18] Wassef, E. A., and Eisawy, A. 1985. "Food and Feeding Habit, of Wild and Reared Gilthead Bream Sparus aurita (L.)." Cybium 9 (3): 233-42.

[19] Rosecchi, E. 1987. "L'alimentation de Diplodus annularis Diplodus sargus, Diplodus vulgaris et Sparus aurata (Pisces, Sparidae) dans le golfe due lion et lagunes littorals." Rev. Trav. Inst. Peches. Marit. 49 (3-4): 125-414.

[20] Rosecchi, E., and Nouaze, Y. 1987. "L'utilization des Alimentaries dans L, analyse des Contenus Stomacaux." Rev Trav. Inst. Peches. Marit. 49 (3-4): 111-23.

[21] Papaconstantinou, C., and Caragitsou, E. 1989. "Feeding Interaction between Two Sympatric Species Pares pagrus and Phycis phycis around Kastellorizo Island (Dodecenese, Greece)." Fish Res. 7: 329-42.

[22] Harvath, M. L., Grimes, C. B., and Huintsman, G. R. 1990. "Growth Mortality, Reproduction and Feeding of Knobbed Porgy Calamus nodosus, Along the South Eastern United State Coast.” Ball. Mar. Sci. 46 (3): 
in Benghazi Coast, Eastern Libya

677-87.

[23] Buxton, C. D., and Clarke, J. R. 1992. "The Biology and Bronze Bream Pachynetopon grande (Teleostei: Sparidae) from the South-East Cape Coast, South Africa." S. Afr. G. Zool. 27 (1): 21 .

[24] Castriota, L., Finoia, M. G., and Andaloo, F. 2005. "Trophic Interactions between Xyrichtys novacula (Labridae) and Juvenile Pares pagrus (Sparidae) in the Central Mediterranean Sea." Electronic Journal Ichthyology 2: 54-60.

[25] Abdel-Rahman, M., and Abdel-Barr, B. 2003. "Biological Studies on Fisheries of Family Sparidae in Alexandria Waters.” Ph.D. Thesis, Alex. Univ. Dep. Of Oceanography.

[26] Osman, E., and Mahmoud, M. 2009. "Feeding Biology of Diplodus sargus and Diplodus vulagaris (teleostei, Sparidae) in Egyptian Mediterranean Waters." W. J. of $F$. and Mar. Sci. 1 (4): 290-6.
[27] Motaref, S. 2013. "Characterization and Biological Study on Some Species of Family Sparidae in Ain El-Ghazala Gulf of Eastern Libya.” M.Sc. Thesis, Univ. of Omar Al Mukhtar.

[28] Anato, C. B., and Ktari, M. H. 1983. "Régime alimentaire de Boops boops (Linné. 1758) et de Sarpa salpa(Linné. 1758), Poissons Téléostéens Sparides du Golfe du Tunis." Rapp. P.-V. Réun. Comm. Int. Explor. Sci. Mer Mediterr. 28: 33-4.

[29] Bell, J. D., and Harmelin-Vivien, M. L. 1983. "Fish Fauna of French Mediterranean Posidonia Oceanica Seagrass Meadows. 2. Feeding Habits." Tethys 11: $1-14$.

[30] Sánchez-Velasco, L., and Norbis, W. 1997. "Comparative Diets and Feeding Habits of Boops boops and Diplodus sargus Larvae, Two Sparid Fishes Co-occurring in the Northwestern Mediterranean.” Bull. Mar. Sci. 61 (3): 821-35. 